3 進化するDVDアプリケーション

\title{
3-3 DVDカーナビゲーション
}

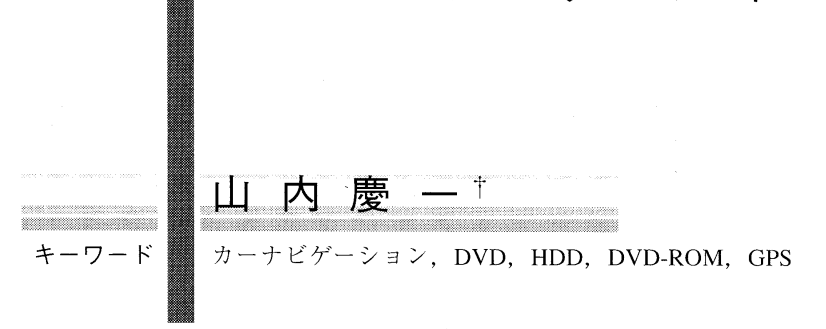

\section{1.まえがき}

1990年に市販で最初のGPSカーナビゲーションシステム が発売されて以来, カーナビゲーションシステムは, その 後の10年間進化し続けている. 当初の地図の媒体はCDROMであり，日本全国を4枚のディスクでカバーしていた が，地図の情報量やその他の付加情報が膨大となり最終的 には，10枚での全国対応となった。このような状況から， 次世代大容量メディアの早期の登場が望まれていた。この 要望を受けて，1997年に最初のDVD-ROMを採用したカー ナビゲーションシステムが商品化された. 大容量のDVDROMの採用により，日本全国が1枚のディスクで収容でき， 瞬く間に，CD-ROMからDVD-ROMへのメディアチェンジ が起きた。さらに2層のDVD-ROMの採用により，DVDカ ーナビゲーションは進化し続け，昨年発売されたHDDカー ナビゲーションでは，地図情報はHDD (ハードディスク)に 蓄積され，リア席でのDVDビデオ鑑賞しながらのカーナビ ゲーション動作が可能となった。ここでは，カーナビゲー ションの基本技術の解説と最近の動向に関して解説を行う.

\section{2. カーナビゲーションの基本技術}

\section{1 基本的なシステム構成}

DVDナビゲーションの代表的なブロック図を図1に示す. 本システムでは，GPSレシーバからの絶対位置情報と3D (3 次元) センサの情報から, 正確な緯度・経度・高さデー夕 を算出し，DVD-ROMから道路情報を用いてマップマッチ ングを行うことで最終的な位置情報を算出する。地眓デー 夕に関しては，DVD-ROMディスクから呼び出しを行い， 描画ICが描画を行い，ディスプレイ上に表示を行う。この 時，上記で算出された自車位置が，画面の中央に来るよう に，地図表示と自車位置の表示を行う。車が移動したとき は，自車位置を中央に固定して，地図をスムーズ・スクロ ールさせる。ヒューマンインタフェースに関しては，リモ

\section{†パイオニア株式会社: 研究開発本部 総合研究所 開発統括部} モーバイルシステム開発部

"DVD Car Navigation" by Keiichi Yamauchi (Mobile Systems Development Department, Development Division, Corporate R\&D Laboratories, Research and Development Group, Pioneer Co., Tokyo)

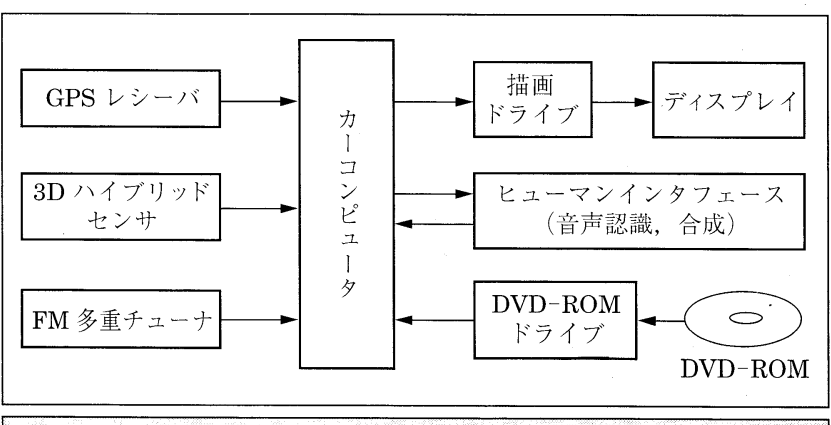

図 1 DVDカーナビゲーションのブロック図

コンやタッチパネル，音声認識/合成等が使用されている が, 安全性の面から音声認識の利用が望まれている.

\subsection{GPS (Global Positioning System)}

現在のカーナビゲーションの絶対位置情報を得るための 基本システムであり，米国が軍事用に開発したものである. このようなGPSなどを用いる航法を電波航法といい, ジヤ イロセンサなどの用いる航法を推測航法, または自立航法 と呼んでいる.

GPSは米国の軍事用として開発されたものであり，軍事 用と民間用が存在する。この民間用の信号は当初, 劣化信 号が付加されており, 測位制度は $100 \mathrm{~m}$ 以内であったが, 2000年5月 1 日にこの信号は解除されており，10m程度の精 度になっている. GPSの基本的な原理は, 衛星からの電波 (時間情報)を受けて, 衛星からの距離を計算し, 現在位置 を算出するもので, 緯度, 経度, 高さ, 時間の4つの未知 数を算出するため，4個の衛星からの電波を受けるのが基 本である. 最近の受信機では, 高精度を得るために5個以 上の衛星を補足するのが基本であり, 多衛星測位方式と呼 ばれている，GPSに関しては，衛星からの信号を受信する 必要があり，トンネルや都心では完全に衛星を補足するの は無理である。このために, 上記の衛星航法と自立航法を 組合せた，ハイブリッド航法が，現在の高級機の位置認識 の主流となっている.

\section{3 ハイブリッド航法}

自立航法は, 車速パルスやジャイロなどの方位/高さセ ンサを用いて相対位置を算出し, 自車位置を算出する。現 状のナビゲーションでは, 3D (3次元) ハイブリッド・ジャ イロを用いることで, 方位と高さの変化を算出している機 種もある。これらの相対位置情報とGPSから得られた絶対 位置情報, そして, 地図デー夕の道路形状情報とを比較す るマップマッチングを行い, 最終的な自車位置の算出を行 っている.

\subsection{VICS情報}

交通情報を収集し, VICS対応の受信機にその情報を伝送 してくれるシステムで, 光ビーコン, 電波ビーコン, FM 多重の3通りの伝達方法が存在している. 主要な幹線道路 
では光ビーコンが使われ，高速道路では電波ビーコンが， 広域の情報伝達としてはFM多重放送が使用されている。 このVICS情報により，交通規制や交通渋滞が文字や地図 上に表示され，ドライバーは交通状態をリアルタイムで認 識が可能となる。後で説明を行う経路誘導に関しても，こ の渋滞情報から自動的に経路変更を行うナビゲーションも 発売されている.

\section{5 音声認識}

ナビゲーションは, 自動車で運転をしているときの利用 が想定され, 安全性の面から音声認識による制御が可能な ナビゲーションシステムが提案されている。最初は，1,000 単語程度の語彙数を待ち受けるシステムであったが, 最近 では数万語から10万語程度の認識を行う大語裹認識のシス テムも登場している。

ナビゲーションでの音声認識は，基本的には話者を特定 しない不特定話者認識であるが，認識率の向上のために話 者学習を行うシステムもある. ナビゲーションでは走行状 態での認識率の向上が技術的には行われており, 走行騒音 を考慮したモデル化を行い, あるいは複数のマイクを使用 するなど様々な工夫が行われている.

\section{6 地図表示}

当初のシステムでは，2次元の地図を自車位置を中心と して，スクロールさせるシステムであった. 最近では，こ れが3次元の地図表示や実写の地図を用いたシステムも出 てきており，様々な地図表示の提案がされている．代表的 なのは, 飛んでいる飛行機から見るような地図表示であり, バードビューやスカイビューとも呼ばれている。これらの 表示では3次元表示が行われている. また, 上記の2次元と 3次元を組合せた，ナイヤガラビューと呼ばれているハイ ブリッドな表示も行われている.

ディスプレイに関しては，10年前の当時は4インチディ スプレイが使用されていたが，最近では8インチのワイド が最大である。一般的にはワイドのQVGAが主流であるが, VGA夕イプのディスプレイも登場し, 画像品質はかなり向 上している.

\section{7 目的地検索, 経路探索, 誘導}

目的地の検索に関しては, 電話番号や住所から検索が可 能で, その他, ジャンルでの検索やテーマ別での検索が可 能となっている，検索が終了すると経路探索が行われ，運 転手に対して経路の提案が行われる．探索時には，有料道 路の考慮や登録ルートの設定も可能であり, いつも通るル 一トに関しては学習を行う機種も存在する。ルート探索が 終了すると, 自動的に音声案内が開始される。最近では, 探索が終了してもVICSからの情報から渋滞を検知して， 自動的にルートを変更するものも登場している.

\section{3. 今後の動向}

1990年に，電波航法であるGPSを利用したカーナビゲー
ションシステムが商品化され，1997年にDVD-ROMを採用 した最初のDVDカーナビゲーションが発売された. 2001年 春には, 地図の媒体としてHDDを採用したHDDカーナビ ゲーションが発売されている.

HDDを採用することで，ルート探索，地図スクロール， 音声認識など，カーナビゲーションの基本機能が大幅に向 上し，さらに再生したCDが自動的にHDDに記録され，ミ ユージックサーバとなる新機能が好評である。今回のHDD ナビゲーションでは，10GBのHDDを採用することで，今 後の地図の増大にも対応が可能なようになっている. HDD 内の地図以外の領域は, 音楽デー夕の記録, そして個人デ ー夕の記録，また，イメージデータなどの画像の記録にも 使用できるようになっている，さらに，追加で10GBの HDDが増設可能となっており，画像データや音楽データが 記録可能となっている。

今回のHDDカーナビゲーションシステムでは, 再生した $\mathrm{CD}$ 音楽がMP3圧縮されて, HDDに自動的に記録される機 能が採用されている，記録された音楽データは自動的に曲 名 (タイトル情報) やアーティスト名, アルバム名が付加さ れ，音声認識で検索が可能となっている．CDに関するこ れらの情報はHDDにあらかじめ記録されている(約 15 万夕 イトル)が，HDDに収納されていない最新の情報は，携帯 電話を通じてインタネット上のデータベースから取得可能 となっている，最初の1台目のHDDでは，CDアルバムで約 20枚の記録が，追加のHDDでは，CDアルバムで約150枚の 記録が可能となっている。

\section{4.むすび}

最初の製品が発売されてから，約 10 年が経過している. この間に，CD-ROMからDVD-ROM，さらにHDDへと媒体 が進化しており，これほど，メディアが変化する商品も非 常にまれのように思える，機能自体も，交通情報への対応， 音声認識インタフェース, 経路探索・案内, 経路を変えた ときの白動リルートなど, 多くの機能が提案され, 実現さ れている. 今後のカーナビゲーションでは, 通信機能との リンクやより使いやすい工夫 (インタフェース) などが大き な課題であり，今後の更なる発展を期待したい。

(2001年11月29日受付)

\section{〔文 献〕}

1）“カーナビゲーション”，パイオニアR\&D特集，9，2（1999）

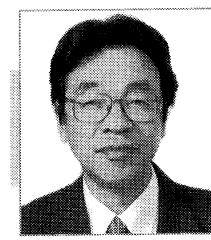

山內 彭一 1977 年, 東北大学大学院修士課程 修了. 同年, パイオニア (株) 入社. 現在, 同社総 合研究所にて，モーバイル関連の研究開発に従事. 